\title{
Pengujian Usability Website Andaru Persada Mandiri Menggunakan Nielsen Attributes of Usability
}

\author{
Hilda Rachmi $^{1 \bowtie)}$, Siti Nurwahyuni ${ }^{2)}$ \\ ${ }^{1)}$ Sistem Informasi Kampus Kota Bogor, Universitas Bina Sarana Informatika, Jakarta-Indonesia \\ hilda.hlr@bsi.ac.id \\ ${ }^{2)}$ Teknologi Informasi, Universitas Bina Sarana Informatika, Jakarta-Indonesia \\ siti.swudbsi.ac.id
}

\begin{abstract}
In pandemics situation, reliance on technology is enormous. All activities are transferred to online, including sales. Sales through the website include the provision of product information which has become very important for the smooth running of the sales and promotion process. To make it easier for users, it is necessary to pay attention to the usability aspect as an indicator for a website that is in accordance with user needs or not. The study conducted a usability test on the Andaru Persada Mandiri website as a provider of laboratory equipment including a tool for carrying out use tests as an initial detection of Corona Virus Disease 19. Testing was carried out through a questionnaire using Nielsen attributes. The test results show that the Andaru Persada Mandiri website fulfills 4 of the 5 test variables according to Nielsen's attributes, namely: learning ability with a value of 3.93 ; memorability with a value of 3.99 ; efficiency with a value of 3.82; and satisfaction with a value of 3.78. It is hoped that the Andaru Persada Mandiri website can fulfill all variables so that it can be well received by its users
\end{abstract}

Keywords—Nielsen Model, Usability Testing, Website.

Intisari-Di masa pandemi seperti saat ini, kebergantungan terhadap teknologi sangat besar. Semua kegiatan dialihkan menjadi berbasis daring termasuk salah satunya adalah penjualan. Penjualan melalui website termasuk didalamnya penyediaan informasi terhadap produk yang disediakan menjadi hal yang sangat penting untuk kelancaran proses penjualan dan promosi. Untuk memudahkan pengguna perlu diperhatikan aspek usability sebagai indikator keberhasilan sebuah website sudah sesuai dengan kebutuhan pengguna atau belum. Penelitian ini melakukan pengujian usability terhadap website Andaru Persada Mandiri sebagai penyedia alat laboratorium yang termasuk di dalamnya alat untuk melakukan tes usap sebagai pendeteksi awal Corona Virus Disease 19. Pengujian dilakukan melalui kuesioner dengan menggunakan model Nielsen. Hasil pengujian menunjukkan bahwa website Andaru Persada Mandiri memenuhi 4 variabel dari 5 variabel pengujian menurut atribut Nielsen, yaitu: learnability dengan nilai 3,93; memorability dengan nilai 3,99; efficiency dengan nilai 3,82; dan satisfaction dengan nilai 3,78. Ke depannya diharapkan website Andaru Persada Mandiri dapat memenuhi seluruh variabel agar dapat diterima dengan baik oleh penggunanya

Kata kunci-Model Nielsen Model, Pengujian Kebergunaan, Website.

\section{PENDAHULUAN}

PT. Andaru Persada Mandiri adalah perusahaan yang bergerak dalam pendistribusian alat laboratorium yang mulai berjalan sejak tahun 2009 hingga saat ini. Di masa pandemi saat ini permintaan akan peralatan laboratorium, salah satunya peralatan swab dan PCR untuk pendeteksian Corona Virus Diasese 19 sangat meningkat. Andaru Persada Mandiri membutuhkan sebuah media yang dapat memudahkan dalam menyampaikan informasi ke seluruh konsumen dan pengguna alat laboratorium yang ada pada perusahaan, sehingga perusahaan memutuskan untuk membuat sebuah website yang dapat dijangkau oleh siapapun, kapanpun, dimanapun asalkan perangkat yang digunakan terhubung dengan internet. Banyak perusahaan yang semakin memikirkan pentingnya kunci sukses dalam memenangkan persaingan dunia bisnis sangat bergantung pada kemampuan perusahaan untuk mendapatkan informasi yang berguna secara cepat dan tepat yang bertumpu pada nominal investasi [1]. Penggunaan teknologi informasi menjadi salah satu investasi yang banyak dipilih oleh perusahaan.

Melihat banyaknya aplikasi dan sistem yang saat ini telah dibuat dan bahkan dikembangkan oleh para programer serta melihat kebutuhan perusahaan yang membutuhkan aplikasi dalam bentuk website atau desktop [2], maka PT. Andaru Persada Mandiri menggunakan media website dalam mengembangkan kemampuan perusahaan, agar perusahaan dapat lebih dikenal lagi dikalangan masyarakat. Saat ini website Andaru PM (andarupm.co.id) sudah dapat diakses oleh siapa saja yang membutuhkan informasi terkait alat-alat laboratorium. Kualitas web akan sangat berpengaruh terhadap tingkat kepuasan penggunanya itu sendiri. Semakin tinggi kualitas suatu web, maka akan semakin banyak pengguna yang mengakses web tersebut. Keterlibatan pengguna dalam pemanfaatan teknologi sistem informasi sangat menentukan 
akan keberhasilan sebuah kualitas sistem dan informasi yang diproduksinya) [3].

Website harus menyenangkan untuk digunakan dan dilihat. Persepsi pengguna atas kesenangan mempengaruhi mereka dalam anggapan mudah digunakan, motivasi untuk belajar bagaimana menggunakan website, keyakinan [2]. Untuk itu dibutuhkan evaluasi mengenai bagaimana kinerja website Andaru PM dalam menyampaikan informasi kepada para pengguna yang menggunakan website untuk mencari informasi yang mereka dibutuhkan. Untuk mengetahui sejauh mana kepuasan pengguna dalam menggunakan website Andaru PM dapat menggunakan teknik usability sebagai alat pengukuran [4]. Untuk menguji sebuah aplikasi web dapat dilakukan pada karakteristik functional suitability, compability, usability, dan performance efficiency [5]. Pengujian usability dapat dilakukan dengan metode heuristic evaluation dan sistem usability scale. Heuristic evaluation merupakan teknik pengukuran usability yang melibatkan ahli dalam melakukan pemberian nilai, sedangkan pada sistem usability scale melibatkan pengguna (end user) [6]. Usability dapat digunakan untuk mengukur kebergunaan perangkat lunak berbasis desktop, web, maupun mobile [4]. Pengukuran kepuasan juga dapat dilakukan dengan metode Nielsen Attributes of Usability (NAU) [7].

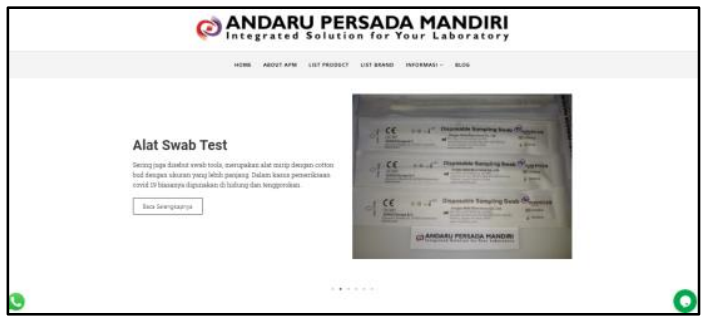

Gambar 1. Tampilan website Andaru Persada Mandiri

Analisis usability dengan menggunakan model Nielsesn sebelumnya sudah digunakan untuk menguji kebergunaan aplikasi MyTelkomsel. Hasil dari penelitian tersebut menunjukkan bahwa memorability dan satisfaction sangat berpengaruh terhadap pengguna aplikasi [8]. Evaluasi Usability Test e-Repository menggunakan Metode Nielsen's Attributtes of Usability di AMIK Indonesia dengan sampel pengguna sebanyak 22 orang mahasiswa. Dari hasil penelitian, tingkat ketidakberhasilan pada pengujian Usability Test ke 7, 8, dan 10 dengan capaian kurang dari $80 \%$ responden gagal menjawab. Untuk tingkat keberhasilan diatas $80 \%$ pada pengujian pengujian Usability Test ke-1 sampai 6 , dan pengujian Usability Test ke-9 [7]. Peneliti lain yang melakukan usability testing menggunakan paket pengujian SUS (System Usability Scale) untuk mengukur usability desain aplikasi dan SEQ (Single Ease Question) untuk mengukur tingkat kemudahan setiap fungsi desain aplikasi yang dikembangkan. Komparasi dilakukan antara sistem eReader yaitu Digilib UAD dengan desain aplikasi eReader skripsi hypertext. Sebanyak lima belas responden yang menggunakan eReader skripsi Digilib UAD dan lima belas responden yang menggunakan desain aplikasi eReader berbasis hypertext. Hasil pengujian menunjukkan bahwa skor SUS desain aplikasi eReader skripsi hypertext adalah sebesar 82.2 [9]. Sedangkan usability menggunakan heuristic evaluation dilakukan pada website Universitas Brawijaya dimulai dengan melakukan pengumpulan data, pengujian website, dan analisis hasil heuristik dan uji preferensi user [10].

Pada penelitian ini akan dilakukan pengujian evaluasi terhadap website Andaru PM menggunakan metode Nielsen Attributes of Usability (NAU) untuk mengetahui sejauh mana manfaat yang sudah dirasakan pengguna serta kenyamanan pengguna saat menggunakan website Andaru Persada Mandiri untuk mencari informasi yang mereka butuhkan. Hasil dari penelitian ini diharapkan dapat menjadi dasar pengambilan keputusan untuk meningkatkan kinerja website dalam menyampaikan informasi terkait profil perusahaan dan produk-produk yang terdapat di perusahaan ini, sehingga perusahaan bisa lebih dikenal dan dapat meningkatkan daya jual terhadap produk yang ada diperusahaan.

\section{TINJAUAN LITERATUR}

Menurut Jacob Nielsen dalam [2], usability adalah atribut kualitas yang menjelaskan atau mengukur seberapa mudah penggunaan suatu antar muka (interface). Kata "usability" merujuk pada suatu metode untuk meningkatkan kemudahan pemakaian selama proses desain [9]. Usabilty juga dapat diartikan tingkat kualitas dari sistem yang mudah dipelajari, mudah digunakan dan mendorong pengguna untuk menggunakan sistem sebagai alat bantu positif dalam menyelesaikan tugas [11].

Menurut Bauer dalam [12] usability testing adalah mengukur efisiensi, kemudahan dalam mempelajari, dan kemampuan untuk mengingat bagaimana berinteraksi tanpa mengalami kesulitan. Usability testing dapat dilakukan dengan melakukan tahapan-tahapan sebagai berikut [13]:

1. Pemilihan kuisioner: memilih paket kuisioner yang akan digunakan. Setiap paket kuisioner memiliki asumsi dasar tertentu, kerangka pemikiran dan pendekatan yang berbeda-beda.

2. Memilih partisipan: menentukan partisipan yang representatif, membagi berdasarkan kelompok seperti umur, jenis kelamin dan lain-lain.

3. Menentukan ukuran sampel: menentukan ukuran partisipan yang representatif untuk dijadikan obyek pengumpulan data.

4. Mengolah dan interpretasi data sesuai dengan karakteristik data penelitian.

Kuesioner usability testing yang dapat digunakan adalah: Kuesioner untuk User Interface (QUIS) oleh Chin, Perceived Usefulness and Ease of Use (PUEU) oleh Davis, Nielsen 'Attributes of Usability (NAU) oleh Nielsen, Nielsen' heuristic evaluasi (NHE) oleh Nielsen, USE Kuesioner: Kegunaan, Kepuasan dan Kemudahan penggunaan (USE) oleh Lund, After Scenario Questionnaire (ASQ) oleh Lewis, Praktek Heuristik untuk Evaluasi Kegunaan (PHUE) oleh Perlman dan Pengujian Kegunaan Purdue kuesioner (PUTQ) oleh Lin [14]. 


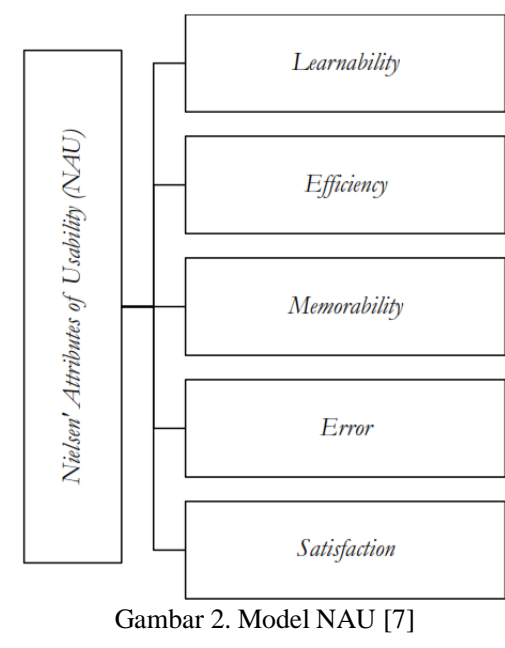

NAU melibatkan 5 kategori usability yaitu; 1) Learnability yang mendeskripsikan tingkat kemudahan pengguna dalam memahami penggunaan dan fungsi-fungsi yang terdapat pada aplikasi, 2) Efficiency yang mendeksripsikan pengukuran kecepatan dan ketepatan pegguna dalam mengakses aplikasi, 3) Memorability yang mendeksripsikan tingkat ingatan pengguna dalam menjalankan sistem, 4) Error yang digunakan untuk mengetahui apakah terdapat fitur yang rusak atau tidak berfungsi pada sebuah aplikasi, dan 5) Satisfaction untuk mengukur tingkat kepuasan pengguna terhadap desain yang ditawarkan oleh aplikasi.

Kuesioner dengan NAU terdiri dari 18 pertanyaan. Tiaptiap pertanyaan akan diberikan 5 peringkat dimulai dari Sangat Tidak Setuju sampai Sangat Setuju [15]. Hasil kuesioner akan dianalisis dengan statistik deskriptif. Menurut Hasan dalam [12] statistik deskriptif atau statistik deduktif adalah bagian dari statistik mempelajari cara pengumpulan data dan penyajian data sehingga muda dipahami.

Dengan kategori yang ditawarkan oleh Nielsen' Attributes of Usability (NAU) Model sangat tepat digunakan untuk mendapatkan hasil kuantitatif serta menggunakan metode pengambilan data kualitatif dalam bentuk kuisioner Nielsen' Attributes of Usability (NAU) [7].

\section{METODE}

Pada penelitian ini data yang digunakan didapatkan dari kuisioner yang telah disebar kepada beberapa responden, guna mendapatkan hasil yang sesuai dengan kebutuhan evaluasi website pada website andaru pm. Sebelum mengisi kuesioner ini responden dipastikan telah mengunjungi website Andaru Persada Mandiri di laman https://andarupm.co.id/. Untuk setiap pertanyaan akan diberikan pilihan jawaban berdasarkan kesesuaian pendapat responden dengan skala 1-5. Adapun urutan skala yang digunakan adalah sebagai berikut: $1=$ Sangat Tidak Setuju, 2 = Tidak Setuju, 3 = Ragu-ragu, $4=$ Setuju, dan $5=$ Sangat Setuju.

Tabel 1. Daftar Pertanyaan

\begin{tabular}{|c|l|}
\hline No. & \multicolumn{1}{|c|}{ Butir Pertanyaan } \\
\hline 1 & Saya dapat mempelajari website dengan mudah \\
\hline 2 & $\begin{array}{l}\text { Saya dapat mempelajari penggunaan website tanpa instruksi } \\
\text { tertulis }\end{array}$ \\
\hline 3 & Saya memperoleh informasi yang spesifik dengan mudah \\
\hline 4 & $\begin{array}{l}\text { Saya memahami konten informasi yang disajikan dengan } \\
\text { mudah }\end{array}$ \\
\hline
\end{tabular}

\begin{tabular}{|c|c|}
\hline 5 & Saya dapat memahami alur navigasi dengan mudah \\
\hline 6 & Saya dapat mengakses fitur dengan cepat \\
\hline 7 & Saya dapat memperoleh informasi yang dicari dengan cepat \\
\hline 8 & Saya dapat melakukan tugas pengujian dengan cepat dan tepat \\
\hline 9 & Saya mengingat cara penggunaan website dengan mudah \\
\hline 10 & $\begin{array}{l}\text { Saya dapat mengingat setiap alur navigasi menu dan letak } \\
\text { informasi yang diinginkan dengan mudah }\end{array}$ \\
\hline 11 & $\begin{array}{l}\text { Saya dapat mengingat cara penggunaan website ini jika saya } \\
\text { menggunakannya setelah beberapa lama ( }>1 \text { bulan) }\end{array}$ \\
\hline 12 & Saya menemukan error di saat menggunakan website \\
\hline 13 & Saya tidak berhasil menemukan menu yang ingin dicari \\
\hline 14 & Jika saya melakukan kesalahan saat menggunakan website \\
\hline 15 & $\begin{array}{l}\text { Saya kesulitan dalam memperbaikinya, saya merasa senang } \\
\text { secara keseluruhan dengan tampilan desain website }\end{array}$ \\
\hline 16 & $\begin{array}{l}\text { Penggunaan website sesuai dengan ekspektasi dari usaha yang } \\
\text { saya miliki }\end{array}$ \\
\hline 17 & Saya merasa nyaman dalam menggunakan website \\
\hline 18 & $\begin{array}{l}\text { Saya akan merekomendasikan website ini kepada rekan atau } \\
\text { sahabat }\end{array}$ \\
\hline
\end{tabular}

Kuesioner dapat dikatakan valid jika merepresentasikan atau mengkur apayang hendak diukur. Pada penelitian ini dilakukan uji validitas dan reliabilitas data. Uji validitas dilakukan menggunakan KMO (Kaiser-Maiyer-Oikin) yang memiliki rentang nilai 0,9-1,0 untuk kategori data sangat baik (Marvelous); 0,8-0,9 untuk kategori data baik (Meritorious); 0,7-0,8 untuk kategori data cukup (Middling); 0,6-0,7 untuk kategori data kurang (Mediocre); 0,5-0,6 untuk kategori data buruk (Miserable); dan $<0,5$ kategori data tidak dapat diterima (Unacceptable).

Tabel 2. Hasil Uji Validitas Pertanyaan

\begin{tabular}{|c|c|c|c|}
\hline No. & Butir Pertanyaan & Koefisien Korelasi & Keterangan \\
\hline 1 & Learnability 1 & 0,920 & Data Sangat Baik \\
\hline 2 & Learnability 2 & 0,940 & Data Sangat Baik \\
\hline 3 & Learnability 3 & 0,948 & Data Sangat Baik \\
\hline 4 & Learnability 4 & 0,944 & Data Sangat Baik \\
\hline 5 & Learnability 5 & 0,947 & Data Sangat Baik \\
\hline 6 & Efficiency 1 & 0,918 & Data Sangat Baik \\
\hline 7 & Efficiency 2 & 0,918 & Data Sangat Baik \\
\hline 8 & Efficiency 3 & 0,926 & Data Sangat Baik \\
\hline 9 & Memorability 1 & 0,916 & Data Sangat Baik \\
\hline 10 & Memorability 2 & 0,924 & Data Sangat Baik \\
\hline 11 & Memorability 3 & 0,939 & Data Sangat Baik \\
\hline 12 & Error 1 & 0,724 & Data Cukup \\
\hline 13 & Error 2 & 0,684 & Data Kurang \\
\hline 14 & Error 3 & 0,761 & Data Cukup \\
\hline 15 & Satisfaction 1 & 0,913 & Data Sangat Baik \\
\hline 16 & Satisfaction 2 & 0,864 & Data Baik \\
\hline 17 & Satisfaction 3 & 0,934 & Data Sangat Baik \\
\hline 18 & Satisfaction 4 & 0,889 & Data Baik \\
\hline
\end{tabular}

Uji reliabilitas dilakukan untuk melihat apakah alat pengukur memiliki nilai konsisten. Hasil uji reliabilitas diukur dengan nilai Cronbach Alpha. Jika nilai tersebut positif dan $\geq 0,70$, maka data kuesioner memiliki reliable. Tingkat reliabilitas berbanding lurus dengan nilai Cronbach Alpha.

Tabel 3. Hasli Uji Reliabilitas Pertanyaan

\begin{tabular}{|l|l|c|c|}
\hline No. & Variabel & Cronbach Alpha & Keterangan \\
\hline 1 & Learnability & 0,891 & Sangat Reliable \\
\hline 2 & Memorability & 0,783 & Sangat Reliable \\
\hline 3 & Efficiency & 0,748 & Sangat Reliable \\
\hline 4 & Error & 0,826 & Sangat Reliable \\
\hline 5 & Satisfaction & 0,739 & Sangat Reliable \\
\hline
\end{tabular}

Berdasarkan tabel diatas kelima variabel memiliki nilai ukur yang sangat reliable karena nilai Cronbach Alpa $\geq 0,70$. 


\section{HASIL}

Setelah kuisioner diberikan, selanjutnya adalah mengolah data hasil pengisian kuesioner. Isian kuesioner yang dikumpulkan dari 207 responden dianalisis dengan analisis statistic deskriptif untuk mendapatkan nilai mean, median, dan modus. Perhitungan dilakukan menggunakan aplikasi SPSS dengan fitur analyze, frequencies, dan descriptive statistics.

Penghitungan mean dimaksudkan untuk mendapat nilai rata-rata dari jawaban responden untuk pertanyaan yang sudah diberikan melalui kuesioner. Berdasarkan perhitungan dengan menggunakan skala likert, diasumsikan nilai mean akan merepresentasikan hasil berikut:

Nilai $1-1,5=$ Responden menyatakan sangat tidak setuju Nilai 1,6-2,5 = Responden menyatakan tidak setuju

Nilai 2,6-3,5 = Responden menyatakan netral

Nilai 3,6-4,5 = Responden menyatakan setuju

Nilai 4,6-5= Responden menyatakan sangat setuju

Penghitungan nilai median menggambarkan nilai tengah dari hasil data yang didapatkan berdasarkan jawaban responden. Penghitungan modus menggambarkan jawaban yang paling sering dipilih oleh responden saat mengisi kuesioner.

A. Variabel Learnability

Berikut penghitungan persentase jawaban yang diberikan responden terkait variabel learnability berdasarkan pertanyaan nomor 1-5:

Tabel 4. Persentase Jawaban Learnability
\begin{tabular}{|c|c|c|c|c|c|}
\hline & $\mathbf{1}$ & $\mathbf{2}$ & $\mathbf{3}$ & $\mathbf{4}$ & $\mathbf{5}$ \\
\hline $\mathbf{X 1}$ & $2,1 \%$ & $3,1 \%$ & $18 \%$ & $47,9 \%$ & $28,9 \%$ \\
\hline $\mathbf{X 2}$ & $6,2 \%$ & $8,2 \%$ & $28,4 \%$ & $30,4 \%$ & $26,8 \%$ \\
\hline $\mathbf{X 3}$ & $1,6 \%$ & $1,6 \%$ & $17,5 \%$ & $47,9 \%$ & $31,4 \%$ \\
\hline $\mathbf{X 4}$ & $1,6 \%$ & $1 \%$ & $20,1 \%$ & $45,9 \%$ & $31,4 \%$ \\
\hline $\mathbf{X 5}$ & $2,1 \%$ & $2,6 \%$ & $24,2 \%$ & $44,8 \%$ & $26,3 \%$ \\
\hline Average & $2,7 \%$ & $3,3 \%$ & $21,6 \%$ & $43,4 \%$ & $29 \%$ \\
\hline
\end{tabular}

Berdasarkan data pada tabel dapat lihat hanya $6 \%$ dari total responden yang memilih jawaban 1 dan 2, sedangkan $21,6 \%$ responden memilih jawaban 3, dan untuk jawaban 4 dan 5 menjadi jawaban terbanyak yang dipilih dengan total rata-rata untuk jawaban tersebut sebesar $72,4 \%$.

Tabel 5. Hasil Jawaban Responden Berdasarkan Indikator Learnability
\begin{tabular}{|c|l|}
\hline Indikator & \multicolumn{1}{|c|}{ Hasil } \\
\hline $\begin{array}{c}\text { Easy to understand } \\
\text { (Pertanyaan 1) }\end{array}$ & $\begin{array}{l}\text { Responden setuju desain website } \\
\text { Andaru Persada Mandiri mudah } \\
\text { dipelajari dengan nilai rata-rata } \\
\text { jawaban 3,98 }\end{array}$ \\
\hline $\begin{array}{l}\text { Easy to look for specific } \\
\text { information (Pertanyaan }\end{array}$ & $\begin{array}{l}\text { Andaru Persada den setuju desain website } \\
\text { memudahkan penggunanya dalam } \\
\text { mendapatkan informasi yang } \\
\text { spesifik dengan nilai rata-rata } \\
\text { jawaban 3,85 }\end{array}$ \\
\hline
\end{tabular}

\begin{tabular}{|c|l|}
\hline & $\begin{array}{l}\text { Responden setuju desain website } \\
\text { Andaru Persada Mandiri }\end{array}$ \\
memudahkan pengguna untuk \\
Easy to identify \\
navigational mechanism \\
(Pertanyaan 4-5) \\
memahamal mekanisme navigasi dan \\
website dengan nilai rata-rata \\
jawaban 3,98
\end{tabular}

Hasil pada tabel menunjukkan bahwa responden setuju desain website Andaru Persada Mandiri memenuhi aspek learnability dibuktikan dengan nilai rata-rata jawaban secara keseluruhan untuk variabel learnability sebesar 3,93.

\section{B. Variabel Memorability}

Berikut penghitungan persentase jawaban yang diberikan responden terkait variabel memorability berdasarkan pertanyaan nomor 6-8:

Tabel 6. Persentase Jawaban Memorability
\begin{tabular}{|c|c|c|c|c|c|}
\hline & $\mathbf{1}$ & $\mathbf{2}$ & $\mathbf{3}$ & $\mathbf{4}$ & $\mathbf{5}$ \\
\hline $\mathbf{X 6}$ & $1,5 \%$ & $3,6 \%$ & $13,4 \%$ & $42,3 \%$ & $39,2 \%$ \\
\hline $\mathbf{X 7}$ & $1 \%$ & $3,1 \%$ & $18,6 \%$ & $43,3 \%$ & $34 \%$ \\
\hline $\mathbf{X 8}$ & $2,5 \%$ & $6,7 \%$ & $23,2 \%$ & $45,4 \%$ & $22,2 \%$ \\
\hline Average & $1,7 \%$ & $4,4 \%$ & $18,4 \%$ & $43,7 \%$ & $31,8 \%$ \\
\hline
\end{tabular}

Total responden yang memlih jawaban 1 dan 2 sebanyak $6,1 \%$, sedangkan responden yang memilih jawaban 3 sebanyak $18,4 \%$, dan jawaban terbanyak yang dipilih responden adalah 4 dan 5 dengan total $75,5 \%$.

Tabel 7. Hasil Jawaban Responden Berdasarkan Indikator Memorability

\begin{tabular}{|c|l|}
\hline Indikator & \multicolumn{1}{|c|}{ Hasil } \\
\hline Easy to remember & $\begin{array}{l}\text { Responden setuju fitur dan } \\
\text { navigasi pada desain website } \\
\text { Andaru Persada Mandiri serta } \\
\text { (Pertanyaan 6 dan 7) } \\
\text { penggunaan website mudah } \\
\text { diingat dengan nilai rata-rata } \\
\text { jawaban 4,10 }\end{array}$ \\
\hline Easy to reestablish & $\begin{array}{l}\text { Responden setuju website } \\
\text { Andaru Persada Mandiri mudah } \\
\text { untuk digunakan jika pengguna } \\
\text { mengakses kembali dalam kurun } \\
\text { waktu tertentu dengan nilai rata- } \\
\text { rata jawaban 3,78 }\end{array}$ \\
\hline
\end{tabular}

Hasil pada tabel menunjukkan bahwa responden setuju desain website Andaru Persada Mandiri memenuhi aspek memorability dibuktikan dengan nilai rata-rata jawaban secara keseluruhan sebesar 3,99.

\section{Variabel Efficiency}

Penghitungan persentase jawaban yang diberikan responden terkait variabel efficiency berdasarkan pertanyaan nomor 9-11 sebagai berikut:

\begin{tabular}{|c|c|c|c|c|c|}
\hline & 1 & 2 & 3 & 4 & 5 \\
\hline X9 & $3,1 \%$ & $3,1 \%$ & $21,6 \%$ & $43,8 \%$ & $28,4 \%$ \\
\hline X10 & $1,6 \%$ & $4,6 \%$ & $21,6 \%$ & $46,4 \%$ & $25,8 \%$ \\
\hline X11 & $2,1 \%$ & $8,2 \%$ & $34,5 \%$ & $32,5 \%$ & $22,7 \%$ \\
\hline Average & $2,2 \%$ & $5,3 \%$ & $26 \%$ & $40,9 \%$ & $25,6 \%$ \\
\hline
\end{tabular}


Total responden yang memlih jawaban 1 dan 2 sebanyak 7,5\%, sedangkan responden yang memilih jawaban 3 sebanyak 26\%, dan jawaban terbanyak yang dipilih responden adalah 4 dan 5 dengan total $66,5 \%$.

Tabel 9. Hasil Jawaban Responden Berdasarkan Indikator Efficiency

\begin{tabular}{|c|l|}
\hline \multicolumn{1}{|c|}{ Indikator } & \multicolumn{1}{c|}{ Hasil } \\
\hline $\begin{array}{c}\text { Easy to reach quickly } \\
\text { (Pertanyaan 9-10) }\end{array}$ & $\begin{array}{l}\text { Responden setuju fitur pada website } \\
\text { Andaru Persada Mandiri dapat } \\
\text { diakses dengan cepat dan pengguna } \\
\text { dapat memperoleh informasi dengan } \\
\text { cepat berdasarkan nilai rata-rata } \\
\text { jawaban 3,91 }\end{array}$ \\
\hline $\begin{array}{l}\text { Responden setuju pengguna dapat } \\
\text { menyeledaikan tugas dengan cepat } \\
\text { pada website Andaru Persada } \\
\text { Mandiri dengan nilai rata-rata } \\
\text { jawaban 3,65 }\end{array}$ \\
\hline
\end{tabular}

Hasil pada tabel menunjukkan bahwa responden setuju desain website Andaru Persada Mandiri memenuhi aspek efficiency dibuktikan dengan nilai rata-rata jawaban secara keseluruhan untuk variabel eficiency sebesar 3,82.

\section{Variabel Error}

Berikut penghitungan persentase jawaban terkait variabel error berdasarkan 3 pertanyaan dari nomor 12 sampai 14:

\begin{tabular}{|c|c|c|c|c|c|}
\multicolumn{2}{c}{ Tabel 10. Persentase Jawaban Error } \\
\hline $\mathbf{1}$ & $\mathbf{1}$ & $\mathbf{2}$ & $\mathbf{3}$ & $\mathbf{4}$ & $\mathbf{5}$ \\
\hline $\mathbf{X 1 3}$ & $27,8 \%$ & $32,5 \%$ & $13,9 \%$ & $13,9 \%$ & $11,9 \%$ \\
\hline $\mathbf{X 1 4}$ & $24,2 \%$ & $26,3 \%$ & $24,2 \%$ & $15,0 \%$ & $10,3 \%$ \\
\hline Average & $13,4 \%$ & $22,7 \%$ & $41,8 \%$ & $12,3 \%$ & $9,8 \%$ \\
\hline
\end{tabular}

Berdasarkan jawaban responden, persentase paling besar terdapat pada jawaban 1 dan 2 dengan total $49 \%$, sedangkan jawaban 3 hanya dipilih oleh $26,6 \%$ responden, dan responden paling sedikit memilih jawaban 4 dan 5 total rata-rata sebesar $24,4 \%$.

Tabel 11. Hasil Jawaban Responden Berdasarkan Indikator Error

\begin{tabular}{|c|c|}
\hline Indikator & Hasil \\
\hline $\begin{array}{l}\text { Number of error detected } \\
\quad \text { (Pertanyaan 12) }\end{array}$ & $\begin{array}{l}\text { Responden tidak setuju dengan } \\
\text { adanya error pada website Andaru } \\
\text { Persada Mandiri dengan nilai rata- } \\
\text { rata jawaban } 2,49\end{array}$ \\
\hline $\begin{array}{l}\text { Easy to fix (Pertanyaan } \\
13-14)\end{array}$ & $\begin{array}{lrr}\text { Responden menyatakan } & \text { netral } \\
\text { terhadap kesulitan } & \text { untuk } \\
\text { memperbaiki kesalahan } & \text { yang } \\
\text { dilakukan saat mengakses } & \text { website } \\
\text { Andaru Persada Mandiri } & \text { dengan } \\
\text { nilai rata-rata jawaban 2,72 } & \end{array}$ \\
\hline
\end{tabular}

Hasil pada tabel menunjukkan bahwa responden netral website Andaru Persada Mandiri memenuhi aspek error dalam penilaian adanya error yang terdeteksi dan kesulitan dalam memperbaiki kesalahan dibuktikan dengan nilai ratarata jawaban secara keseluruhan untuk variabel error sebesar 2,64 .

\section{E. Variabel Satisfaction}

Berikut persentase penghitungan jawaban yang diberikan responden terkait variabel satisfaction dari 4 pertanyaan pada nomor $15-18$ :

Tabel 12. Persentase Jawaban Satisfaction

\begin{tabular}{|c|c|c|c|c|c|}
\hline & 1 & 2 & 3 & 4 & 5 \\
\hline X15 & $6,2 \%$ & $9,3 \%$ & $23,7 \%$ & $40,2 \%$ & $20,6 \%$ \\
\hline X16 & $4,1 \%$ & $3,6 \%$ & $33 \%$ & $41,3 \%$ & $18 \%$ \\
\hline X17 & $10 \%$ & $3,6 \%$ & $23,2 \%$ & $44,8 \%$ & $27,4 \%$ \\
\hline X18 & $2,1 \%$ & $3,1 \%$ & $23,7 \%$ & $42,3 \%$ & $28,8 \%$ \\
\hline Average & $3,3 \%$ & $4,9 \%$ & $25,9 \%$ & $42,2 \%$ & $23,7 \%$ \\
\hline
\end{tabular}

Total responden yang memilih jawaban 1 dan 2 hanya sebesar $8,2 \%$, sedangkan responden yang memilih jawaban 3 sebanyak $25,9 \%$, dan yang paling banyak dipilih responden adalah jawaban 4 dan 5 dengan total rata-rata $65,9 \%$.

\begin{tabular}{|c|c|}
\hline Indikator & Hasil \\
\hline $\begin{array}{l}\text { System pleasant to use } \\
\text { (Pertanyaan 15) }\end{array}$ & $\begin{array}{l}\text { Responden setuju dengan tampilan desain } \\
\text { website Andaru Persada Mandiri secara } \\
\text { keseluruhan dan rata-rata jawaban adalah } \\
3,6\end{array}$ \\
\hline $\begin{array}{c}\text { Comfort to use (Pertanyaan } \\
16-18)\end{array}$ & $\begin{array}{l}\text { Responden setuju website Andaru } \\
\text { Persada Mandiri nyaman untuk } \\
\text { digunakan dan memiliki komposisi warna } \\
\text { serta peletakan konten yang tidak } \\
\text { membingungkan dengan nilai rata-rata } \\
\text { jawaban } 3,84\end{array}$ \\
\hline
\end{tabular}

Hasil pada tabel menunjukkan bahwa responden setuju desain website Andaru Persada Mandiri memenuhi aspek satisfaction dengan nilai rata-rata jawaban secara keseluruhan sebesar 3,78.

Berdasarkan hasil keseluruhan terhadap pengujian statistik deskriptif maka hasil ringkasan statistik deskriptif pada kuesioner Nielsen Attributes of Usability sebagai berikut:

\begin{tabular}{|c|c|c|c|c|}
\hline Variabel & Indikator & Mean & Modus & Hasil \\
\hline \multirow{4}{*}{ Learnability } & Easy to understand & 3,98 & 4 & Setuju \\
\hline & $\begin{array}{l}\text { Easy to look for } \\
\text { specific information }\end{array}$ & 3,85 & 4 & Setuju \\
\hline & $\begin{array}{l}\text { Easy to identify } \\
\text { navigational } \\
\text { mechanism }\end{array}$ & 3,98 & 4 & Setuju \\
\hline & \multicolumn{3}{|l|}{ Learnability $=3,93$} & Setuju \\
\hline \multirow{3}{*}{ Memorability } & Easy to remember & 4,1 & 4 & Setuju \\
\hline & Easy to reestablish & 3,78 & 4 & Setuju \\
\hline & \multicolumn{3}{|l|}{ Memorability $=3,99$} & Setuju \\
\hline \multirow{3}{*}{ Efficiency } & Easy to reach quickly & 3,91 & 4 & Setuju \\
\hline & Easy to navigate & 3,65 & 4 & Setuju \\
\hline & \multicolumn{3}{|l|}{ Efficiency $=3,82$} & Setuju \\
\hline Error & $\begin{array}{l}\text { Number of error } \\
\text { detected }\end{array}$ & 2,49 & 2 & $\begin{array}{l}\text { Tidak } \\
\text { Setuju }\end{array}$ \\
\hline
\end{tabular}




\begin{tabular}{|c|c|c|c|c|}
\hline & Easy to fix & 2,72 & 2 & Netral \\
\hline & \multicolumn{3}{|l|}{ Error $=2,64$} & Netral \\
\hline \multirow{3}{*}{ Satisfaction } & $\begin{array}{l}\text { System pleasant to } \\
\text { use }\end{array}$ & 3,6 & 4 & Setuju \\
\hline & Comfort to use & 3,84 & 4 & Setuju \\
\hline & \multicolumn{3}{|l|}{ Satisfaction $=3,78$} & Setuju \\
\hline
\end{tabular}

Berdasarkan hasil tabel di atas, maka terlihat bhawa website Andaru Persada Mandiri memenuhi 4 variabel learnability, memorability, efficiency, dan satisfaction.

\section{KESIMPULAN}

Berdasarkan hasil analisis usability testing website Andaru Persada Mandiri dapat disimpulkan bahwa Responden menyatakan Setuju bahwa website Andaru Persada Mandiri memenuhi aspek: Learnability dengan nilai rata-rata 3,93, Memorability dengan nilai rata-rata 3,99, Efficiency dengan nilai rata-rata 3,82, Satisfaction dengan nilai rata-rata 3,78. Untuk variabel error responden masih kesulitan dalam mengatasi kesalahan dalam pengujian website sehingga perlu dilakukan pemeriksaan untuk mengatasi faktor kegagalan tersebut. Website PT Andaru Persada Mandiri menunjukkan kinerja yang baik dalam menyampaikan informasi terkait profil perusahaan dan produk-produk yang terdapat di perusahaan ini dan mamiliki tingkat kepuasan yang baik untuk pengguna.

\section{UCAPAN TERIMA KASIH}

Penullis menyampaikan terima kasih kepada pihak Andaru Persada Mandiri dan berbagai pihak yang telah membantu penelitian ini sesuai dengan jadwal yang direncanakan.

\section{DAFTAR PUSTAKA}

[1] Miswanto, H. Sulistiani, and Damayanti, "PENERAPAN METODE COST AND BENEFIT ANALYSIS DALAM PENGUKURAN INVESTASI TEKNOLOGI INFORMASI ( STUDY KASUS : CV LAUT SELATAN JAYA ) The Application of Cost and Benefit Analysis Methods in Measuring Information Technology Investment ( Case Study : CV Laut Sel," J. Tekno Kompak, vol. 14, no. 1, pp. 54-61, 2020.

[2] A. Supriyatna, "Penerapan Usability Testing Untuk Pengukuran," J. Ilm. Teknol. - Inf. dan Sains Vol., vol. 8, no. 1, pp. 1-16, 2018.

[3] I. G. N. S. Wijaya, "Analisis Kepuasan Pengguna ELearning Menggunakan Metode Kano,” J. Sist. fan Inform., no. April, pp. 128-138, 2019.

[4] B. Tujni and F. Syakti, "Implementasi Sistem Usability Scale Dalam Evaluasi Perspektif Pengguna Terhadap Sistem Informasi Akademik Berbasis Mobile," Ilk. J. Ilm., vol. 11, no. 3, pp. 241-251, 2019, doi: 10.33096/ilkom.v11i3.479.241-251.

[5] T. A. Ghaffur and Nurkhamid, "Analisis Kualitas Sistem Informasi Kegiatan Sekolah Berbasis Mobile Web Di Smk Negeri 2 Yogyakarta," Elinvo (Electronics, Informatics, Vocat. Educ., vol. 2, no. 1, pp. 94-101, 2017, doi: 10.21831/elinvo.v2i1.16426.

[6] U. Ependi, F. Panjaitan, and Hutrianto, "System Usability Scale Antarmuka Palembang Guide Sebagai Media Pendukung Asian Games XVIII," J. Inf. Syst. Enginnering Bussines Intellegence, vol. 3, no. 2, pp. 101-107, 2017.

[7] T. Iqbal and B. Bahruni, "Evaluasi Usability Test eRepository dengan menggunakan Metode Nielsen's Attributtes of Usability (NAU)," J. JTIK (Jurnal Teknol. Inf. dan Komunikasi), vol. 3, no. 2, p. 40, 2019, doi: 10.35870/jtik.v3i2.85.

[8] A. A. Wahid, "Analisis Usability pada Aplikasi MyTelkomsel Berdasarkan Nielsen Model,” pp. 1-8, 2019.

[9] M. I. G. Ardiansyah, "PENGUJIAN USABILITY USER INTERFACE DAN USER EXPERIENCE APLIKASI EREADER SKRIPSI BERBASIS HYPERTEXT," J. Ilm. Teknol. Inf. Terap., vol. II, no. 3, 2016.

[10] B. A. M et al., "Analisis Usability Pada Website Universitas Brawijaya Dengan Heuristic Evaluation,” vol. 3, no. 3, 2016.

[11] W. Handiwidjojo and L. Ernawati, "Pengukuran Tingkat Ketergunaan (Usability) Sistem Informasi Keuangan Studi Kasus : Duta Wacana Internal Transaction (Duwit)," Juisi J. Inform. dan Sist. Inf., vol. 02, no. 01, pp. 49-55, 2016.

[12] D. A. Febrianti, S. H. Wijoyo, and H. M. Az-zahra, "Evaluasi Usability Web UniPin dengan Menggunakan Metode Usability Testing," J. Pengemb. Teknol. Inf. dan Ilmu Komput., vol. 3, no. 11, pp. 10547-10555, 2019.

[13] J. Santoso, "Usability User Interface dan User Experience Media Pembelajaran Kamus Kolok Bengkala Berbasis Android," J. Sist. Dan Inform., vol. 12, no. 2, pp. 174-181, 2018.

[14] S. R. Joseph, K. Letsholo, and H. Hlomani, "A Conceptual Framework for the Mining and Analysis of the Social Media Data," Int. J. Database Theory Appl., vol. 10, no. 10, pp. 11-34, 2017, doi: 10.14257/ijdta.2017.10.10.02.

[15] F. J. García-Peñalvo, A. García-Holgado, A. VázquezIngelmo, and A. M. Seoane-Pardo, "Usability test of WYRED platform," Lect. Notes Comput. Sci. (including Subser. Lect. Notes Artif. Intell. Lect. Notes Bioinformatics), vol. 10924 LNCS, pp. 73-84, 2018, doi: 10.1007/978-3-319-91743-6_5. 